University of Nebraska - Lincoln

DigitalCommons@University of Nebraska - Lincoln

20th \& 21st Century French and Francophone Modern Languages and Literatures, Department Studies International Colloquium

4-2020

\title{
Writing after the Human: Marie Darrieussecq's and Anne Garréta's Posthumanisms
}

Annabel L. Kim

Harvard University, annabel_kim@fas.harvard.edu

Follow this and additional works at: https://digitalcommons.unl.edu/ffsc2020

Part of the Comparative Literature Commons, French and Francophone Literature Commons, and the Other French and Francophone Language and Literature Commons

Kim, Annabel L., "Writing after the Human: Marie Darrieussecq's and Anne Garréta's Posthumanisms" (2020). 20th \& 21st Century French and Francophone Studies International Colloquium. 18.

https://digitalcommons.unl.edu/ffsc2020/18

This Presentation is brought to you for free and open access by the Modern Languages and Literatures, Department of at DigitalCommons@University of Nebraska - Lincoln. It has been accepted for inclusion in 20th \& 21st Century French and Francophone Studies International Colloquium by an authorized administrator of DigitalCommons@University of Nebraska - Lincoln. 
20th \& 21st Century French and Francophone Studies International Colloquium, University of Nebraska-Lincoln, March 26-28, 2020.

https://digitalcommons.unl.edu/ffsc2020/

Copyright @ 2020 Annabel Kim.

Annabel L. Kim

FFSC 2020

"Writing after the Human: Marie Darrieussecq's and Anne Garréta's Posthumanisms"

In our current moment of climate catastrophe and impending planetary doom, the posthuman seems like a harbinger of an all too imminent reality (felt especially keenly in the age of COVID-19). In the twentyfirst century, the humanities, grappling with the multifarious failures and excesses of traditional humanism, are attempting to abandon the anthropocentric epistemologies and practices that have characterized Western thought and culture and to create new models for thinking the world — models that are able to accommodate the nonhuman and welcome other forms of life and matter as objects of focus, moving thus from an imperialist vertical mode of conquering the world to a horizontal one of egalitarian relation between actors hybridized through their mutual entanglement, caught up in one large network, to draw upon thinkers like Bruno Latour and Donna Haraway, to name just two of the major names associated with new materialisms, which we could describe as the contemporary response to the anthropocentric humanisms of preceding centuries.

Literary studies have, in their engagement with posthumanist theoretical and critical approaches, largely dealt with the ways in which literature represents posthumanism, examining characters and plots that decenter the human, which accounts for the way science fiction dominates as a privileged object of literary scholars invested in posthumanism. In these instances, literature is taken as the site for case studies that problematize posthumanism in interesting and valuable ways: take, for example, Kazuo Ishiguro's Never Let Me Go, a popular text for thinking through questions of embodiment and consciousness and the boundaries of human-ness through its representation of human cloning; or the way critic Katherine N. Hayles analyzes science fiction texts by authors such as Philip Dick. Less taken up, however, is the way in which literature itself constitutes a posthuman experience. Certainly, insofar as posthumanism deals with questions of technology and we humans' relation to our various technologies, literature, by employing hypertextuality or responding to things like the Internet and social media, calls attention to itself as the site of posthuman 
experience, recasting literature as something other than the familiar printed volume that grounds the long tradition of letters, thus raising the possibility for other forms that literature's materiality might assume.

Even here, though, in what is called E-literature, or literature that is "born digital," created within an electronic environment, taken by some as the new vanguard of literature-literature's new wild west as it navigates the boundary-pushing that the internet entails-literature remains firmly a human domain, as opposed to, say, the visual and plastic arts, where we can find plenty of examples of animal artistschimpanzees, elephants, dolphins, beluga whales, and rabbits, for instance, are all species that have been successfully trained to draw or paint. And while Koko the gorilla and dolphins might have their capacity for linguistic expression and comprehension acknowledged, they are certainly not considered authors in the same way that even the lowest-brow of authors or self-publishing authors are. What I would like to examine here, today, is the way literature, despite remaining one of the most anthropocentric artifacts that the human species continues to produce - is able to envision and make space for its own transition to being a process or production that is posthuman in the sense of non-human - beyond human, outside the human.

In other words, I want to apply to literature posthumanism's most valuable quality - that is, its capacity to critique a fetishistic, naturalizing, essentializing, transhistorical conception of the human and human exceptionalism. The posthumanist critique that we are readily able to bring to bear on the humanities in general has not yet pierced through to our notion of literature as anything but a human enterprise, as signaled by the perduring quality of literariness as a concept. But it is literature itself that equips us to be able to think, truly, a posthuman literature. Literature, as a human product, is able to transcend the human, as becomes clear in recent works by the contemporary French authors Marie Darrieussecq and Anne Garréta, who, in Notre vie dans les forêts and Dans l'béton, respectively, address posthuman readers, such forms of address compelling us to consider the possibility of a literature without humans, just as we, in the face of our own manufactured climate catastrophe, are forced to consider the possibility of a planet without us. Jeff Wallace, in an incisive article entitled "Literature and Posthumanism," describes literatures of posthumanism as being 
largely about the posthuman, while shifts in technology point to how "the most radical mutation [in literature] is toward new forms of textuality that demonstrate how we might be posthuman." ${ }^{1}$ What Darrieussecq and Garréta instantiate, however, is the reversal of that relation between us, textuality, and the posthuman. What we see in their works are forms of textuality that demonstrate how literature itself is posthuman.

Let's begin with Darrieussecq's Notre vie dans les forêts, published in 2017. This novel is a return to the dystopian genre that launched her career when she published Truismes in 1996, and both feature female narrators who are hunkered down in the forest - taken in both novels as a kind of primordial natural space that exists in opposition to the degraded, developed world outside it. The setting of Notre vie dans les forêts is, as it was in Truismes, the near future. In a world where environmental crises have resulted in a population wracked with illness, and mass extinctions have killed off both the flora and the fauna we associate with our current precarious situation on the planet, income inequality and technological ability have increased to such an extent that the difference between the haves and have-nots has taken the form of the haves being able to live a life of luxury in pristine environments (such as on the beach by pure blue waters), while they prolong their life indefinitely by producing multiple clones whose bodies can be harvested for fresh organs to give a boost to the original. The catch in this scenario is that these clones themselves have clones, so that some of the clones believe that they are the haves, fortunate enough to have another body at their disposition, and these other clones are referred to as their moitiés, or their other halves, who are kept in a medically induced coma while they get to live "normal" lives. The novel tracks the narrator's journey from a docile clone who has no idea what her function is in this economy of organs, to her realization of what she really is as she runs off to the forest to join a group of similarly aware clones who are trying to attack the system by "emancipating" their dormant halves to live off-grid in the forest together. Writing from a place of anguished self-awareness, the narrator recounts how she ended up in the forest.

\footnotetext{
${ }^{1}$ Jeff Wallace, "Literature and Posthumanism: Literature and Posthumanism," Literature Compass 7, no. 8 (August 3, 2010): 696, https://doi.org/10.1111/j.1741-4113.2010.00723.x.
} 
The 21 years that separate the publication of Notre vie dans les forêts from Truismes is evident in a certain cynicism or despair that has worked its way into the narrative voice of the more recent novel that isn't evident in Darrieussecq's debut novel. Truismes begins with an explicit mention of all the trouble that will come to whatever editor will publish the story: "Je sais à quel point cette histoire pourra semer de trouble et d'angoisse, à quel point elle perturba des gens. Je me doute que l'éditeur qui acceptera de prendre en charge ce manuscrit s'exposera à d'infinis ennuis. La prison ne lui sera sans doute pas épargnée, et je tiens à lui demander tout de suite pardon pour le dérangement" (POL 9). This beginning makes clear that the narrator is writing in the hopes of reaching a real, human audience, and the novel's ending insists on the narrator's humanity as she describes her current state: mostly content with her lot as a pig, she becomes human once a month to write and reread her notebook, and to remember what it was to be human. The frame in Truismes is thus one that insists on the humanness of the narrative's author and of its reader.

In Notre vie dans les forêts, on the other hand, there is no such human framework for the narrative. The narrator, Marie, who later takes on the name Viviane when she names her own clone Marie to recognize her humanness, is writing not in the hope of future publication, but rather, first and foremost, to process and understand what has happened and is happening to her: "Du nerf. Il faut que je raconte cette histoire. Il faut que j' essaie de comprendre en mettant les choses bout à bout. En rameutant les morceaux. Parce que ça ne va pas. C'est pas bon, là, tout ça. Pas bon du tout” (9). This « c'est pas bon » refers not only to the catastrophic state of the narrator's own situation — having been harvested for a lung and an eye already, she is dying — but also the catastrophic state of the entire planet, which is in a state of environmental devastation as dire as that of her own body. Marie first addresses herself, knowing she is not for long in the world, and then reaches out beyond herself to address instead an imaginary reader, a speculative vous - "laissez-moi d'abord vous décrire ma situation actuelle" (10) — which, I would submit, is in fact a posthuman, nonhuman reader.

While Marie/Viviane never speculates as to whom a future reader could be, nor what the future holds in store for the planet and for the human species, against the backdrop of the climate catastrophe we 
are living in, where each year brings yet more news of just how quickly we are hurtling toward a point of no return and mass extinction, including our own species, Darrieussecq clearly gestures toward a post-climate catastrophe planet. In the narrator's universe, humans have explored the moon, Mars, Jupiter's satellites, and are on the verge of discovering inhabitable planets, such that Planet Earth will no longer be the center of human life (14). In the narrator's world, mass extinctions have already happened on a far greater scale than what we are currently experiencing, and animals that are still common, like dogs, are available purely through cloning, and zoos, rather than become spaces of preservation of biodiversity, are now sites of reproducing extinct animals through cloning for the gratification of the consumer. Artificial intelligence has progressed to the point that Marie/Viviane's old job as a psychologist entailed in part training robots to identify and understand human emotion to be able to automate therapy. As she puts it wryly, "J'imagine que la dernière forêt aura disparu quand le premier robot humain sera au point. On touche au but. Cinquante ans. Je ne verrai pas ça. Je me déglinguerai avant” (18). It doesn't take too much imagination to conclude that to eliminate all forests is to sign a death sentence for humankind, as least as far as the question of the earth's inhabitability goes. A planet without trees is a planet without a breathable atmosphere, is a planet without the level of biodiversity that is needed to sustain the ecological systems upon which we depend. It isn't for nothing that Darrieussecq maps the elimination of forests onto the replacement of humans by robots, which is how I read the envisioning of a human robot - entities that are physically able to operate on a desolate planet, but with the sentience needed to understand human stories such as the one that the narrator is leaving behind for her hypothetical post-forest reader.

Marie/Viviane imagines the discovery of her text as follows: "Et si on trouve mes ossements avec ce que j' 'écris, si je suis toujours là, momifiée ou je ne sais quoi, avec mon crâne vide et le boîtier tombé au fond, solide et toujours bipant, envoyant toujours ses fichues impulsions dans le néant, dans le bidon, dans la forêt ou ce qui en restera, dans les débris fumants de la forêt carbonisée, le boitier tombé dans le creux de ma boîte crânienne et m'intimant toujours des ordres et des pensées qui, seraient-elles parvenues clairement à ma 
conscience, m'auraient probablement révoltée, je voudrais, s'il vous plaît, lisez ceci comme une prière, je voudrais que vous considériez mes pauvres os, mes pauvres tissus cellulaires secs, que vous les considériez avec la tendresse que les éléphants réservaient à leurs morts. Il parait, autrefois, quand il y avait des éléphants, des éléphants sauvages ou presque, quand il restait des éléphants dans des paysages, il parait qu'ils s'arrêtaient dans des paysages, il parait qu'ils s'arrêtaient dans leur lente et pensive marche. Il paraît qu'ils s'arrêtaient en trouvant les ossements des leurs. Ils contemplaient les longues côtes vides sur le cœur disparu, l'énorme crâne sur les pensées perdues, les longues défenses si elles n'avaient pas été braconnées, la colonne vertébrale aussi longue et solide qu'un chemin de fer. Ils s'arrêtaient, et, de leur trompe mobile, ils entouraient ces morceaux blanchis et il les soulevaient, et ils les balançaient doucement, dans l'air qu'ils respiraient, pour ceux qui ne respiraient plus. Et ils repartaient, lourds et pensifs, contemplant le monde de leurs petits yeux mélancoliques pour ceux qui ne voyaient plus. Je voudrais, s'il vous plaît, si vous trouvez ces ossements dans ce bidon, que vous songiez, quelques secondes, à la femme qui y respirait" (187-89). Her story, like that of Truismes's narrator, is a plea to remember her humanity, despite her clone status and the boitier that has been installed in her brain as a way of tracking her, which makes her a cyborg. But unlike in Truismes, the narrative is directed at a posthuman reader, one who cannot be counted on to understand or conceive of humanity as we do, one whose existence would signal the end of the human and the beginning of something else - a literary encounter that exists entirely outside the human.

Where Darrieussecq raises the possibility of a literally posthuman reader - a nonhuman reader, say, a robot, who picks up the text in an era where humans no longer exist on the planet — Garréta places us in a posthuman now, pointing to the artificial intelligence that has become a part of our experience of the everyday. This explicit posthuman address, this addressing of her text to a posthuman reader, is clear in Garréta's most recent novel, Dans l'béton, which seemingly departs from her cerebral, cynical corpus as it is instead a droll, poignant, and at times even sentimental récit d'enfance, whose experimentation with language and syntax 
garnered the novel comparisons with Raymond Queneau's Zazie dans le métro, with its néofrançais (rather than with the linguistic and syntactical experimentation of Monique Wittig, whose L'Opoponax is a clear intertext for Garréta's novel). Garréta, whose works pose a challenge to her translators on a good day, has with Dans l'béton, produced a novel that defies translation, that is untranslatable. We've seen in the English translation of Zazie dans le métro how Barbara Wright was able to masterfully render Queneau's neologisms in English, turning the famous opening word, Doukipudonktan into Howcanaystinksotho. Garréta's novel is replete with such orthographical experiments, such as her rendering week-end as ouikinde, for which there are any number of possible translations in English, such as weekinned or wecanned. Where Garréta ventures into the untranslatable is with the way her wordplay digs impossibly deep into French to scoop out its semantic and sonorous possibilities like so many pumpkin seeds and spit them out into the text. To give just a few examples:

"Mystère et goules de pomme" (13) — a riff off mystère et boule de gomme, the Garrétian transformation able to replace boule de gomme with actual words. I haven't been able to find an equivalent English expression that lends itself to that kind of transformation.

Next, Garréta has a paragraph where she plays on the closeness of the urie in penurie to urine, carefully working the connection between urine and time: “Moi, j’appelle ça la théorie de la pénurine. Le temps, c'est de l'essence, je disais. [...] J'ai pas de preuve expérimentale, mais il me semble que sous un certain point de vue, c'est comme si le temps, le vrai temps, c'était pas celui des montres et des horloges. Et que le vrai temps, y sfait d'urée." (28-29) Garréta exploits the way in French durée, as a measure and experience of time, contains urée, or urea, so that she's able to commingle the urinary and the temporal through this convergence. There is no such possibility open to English, where the closest we get is the mangled durea-tion.

Finally, at multiple points in the novel, Garréta plays off the polysemy of pédale in French as referring both to a male homosexual and to an actual bike pedal. There is no term in English that comes close to overlapping with cycling nomenclature. Garréta, at the $201820^{\text {th }}$ - and $21^{\text {st }}$-century French and Francophone Studies conference at Brown University, commented on her singular linguistic experimentation by saying that 
she had written the book in order to thwart artificial intelligence as manifested in machine translation (i.e. Google translate). In writing a book so thoroughly untranslatable, she effectively deploys a version of French language that is only recognizable and meaningful to a human reader, who is compelled to concede the linguistic site-specificity of Garréta's work, which acts as a kind of repudiation of the endless portability and mobility that characterizes our epoch. Garréta, in her wish to thwart artificial intelligence and machine translation, would seem to be staking out a position firmly within the human, but I would argue that by naming AI as the antagonistic recipient of her text, or what we would normally call the reader, or framing AI negatively as the text's reader, Garréta's novel emphasizes the necessity of a human reader only by introducing the idea of a non-human one. The human reader's success is built upon the non-human reader's failure, but that failure itself opens the possibility for literature becoming something else, for a beyond of literature whose beyondness may seem to have been exhausted already.

Both Garréta and Darrieussecq, by addressing their texts to nonhuman readers, are laying the ground for a posthuman literature that operates outside or after the human. Both raise the idea of robotic, AI readership that suggests, provocatively, a literature that is not founded on either comprehension or meaning, but entails instead a rawer, less mediated experience of language. What this posthuman literature constitutes is in essence the feralization of literature, a literature that has been freed from human domestication. In this, they follow Nathalie Sarraute, a writer to whom we can track both Darrieussecq and Garréta (Darrieussecq directly to Sarraute, whom she considers a "spiritual grandmother," and Garréta indirectly via Wittig, for whom Sarraute was a foundational influence, Wittig being a major influence on Garréta). Sarraute's corpus can be described as exploring our relation with a language that had been domesticated by social convention and usage, as manifested in the tropismic situations she dedicated her career to capturing. But Sarraute, in her last work, Ouvrez, published after the publication of the Pléiade edition of her Euvres completes, went beyond her previous work to imagine language existing outside the human in her last work, taking the kinds of sub-conversational dramas of the tropism and excising them from a human context to stage instead a purely 
intra-linguistic drama. ${ }^{2}$ However, Sarraute's notion of a nonhuman literature is marked by the preposthumanism of her time and sensibility, as it imagines a literature that is autonomous, independent of a human context, rather than evoking, as do Darrieussecq and Garréta, a literature from which the human has been eliminated because of the extinction of humankind. (Language has its own life, but so do humans still.) What does it mean for literature to be for a nonhuman reader? What does it mean for literature to be nonhuman? These are questions that are posed by Darrieussecq and Garréta's texts, which, rather than declaim the death of the author, point instead to the death of the reader. The reader is dead, long live the reader.

\footnotetext{
${ }^{2}$ It's interesting that it's when her body is failing, as a woman in her 90 s, that she would begin to imagine a literature that exists outside human bodies, for which human embodiment is not relevant.
} 